\title{
CITAÇÃO PELO CORREIO
}

\author{
CLITO FORNACIARI JUNIOR \\ Professor Assistente dos Cursos de Espe- \\ cialização e Bacharelado na Pontifícia Uni- \\ versidade Católica de São Paulo
}

\section{SUMÁRIO}

1. Introdução - 2. Natureza jurídica da função exercida pelo carteiro -3 . Conceito de comerciante -4 . Limites territoriais existentes para a citação pelo correio - 5 . Demandas que ensejam ciłação pelo correio -6 . $O$ destinatário a que se refere o $\S 3 .^{\circ}$ do art. $223-7$. A devolução da carta - 8. O momento de ocorrência dos efeitos da citação (art. 219) quando feita pelo correio - 9. Citação pelo correio e processo de execução.

1. Para que se possa atender ao princípio da bilateralidade da audiência é necessário que se leve ao demandado notícia acerca da ação que contra ele foi proposta. O meio idôneo de se realizar isto é a citação, definida no Código de Processo Civil como "o ato pelo qual se chama a juízo o réu ou o interessado a fim de se defender" (art. 213).

Nosso Código prevê três formas de realização da citação: pelo correio, pelo oficial de justiça e por edital (art. 221). Delas todas a forma mais importante, segundo PONTES DE MIRANDA, é a da citação pelo oficial de justiça (01). Tanto é assim, que tal modalidade é sempre admissível, sendo afastada unicamente diante de previsão legal expressa em sentido contrário (art. 224).

Uma das exceções à regra da citação através do oficial de justiça encontra-se no art. 222 do Código. Por força deste dispositivo legal é possível a ciłação pelo correio "quando o réu for comerciante ou industrial, domiciliado no Brasil".

01. Pontes de Miranda, Comentários ao Código de Processo Civil, Rio de Janeiro, Ed. Forense, 1974, III Tomo, pág. 261. 
Tal forma de citação não se constitui em uma novidade do Código de 1973, uma vez que alguns códigos estaduais já a previam, como o da Bahia (art. 75) e o de São Paulo (art. 182) (02). Outrossim, é a citação postal largamente utilizada na justiça trabalhista e encontra-se disciplinada no campo cível para as ações de alimentos (Lei 5.478, de 25.7.68, art. 5. ${ }^{\circ}$, § 2..$^{\circ}$ ).

A sua utilização, no entanto, a partir do atual Código de Processo Civil, diante da escassa regulamentação dada por este à matéria, tornou-se fonte de dúvidas que procuraremos abordar no âmbito deste trabalho.

2. O primeiro ponto que requer fixação consiste na natureza jurídica da função exercida pelo carteiro quando realiza este ato processual. Estaria ele investido dos atributos de oficial de justiça?

O oficial de justiça é um auxiliar do juízo, encontrando-se subordinado funcional e disciplinarmente ao juiz (03). Tem atribuições expressamente previstas no Código e nas leis de organização judiciária. O carteiro é um estranho às leis de organização judiciária; não está sujeito à disciplina do juízo; não está submetido quando procede com dolo, culpa ou quando se recusa a atender as determinações do juiz à responsabilidade civil a que se refere o art. 144 .

Por outro lado, falta ao carteiro fé pública (04), que é uma das características marcantes do oficial de justiça e que respercute em todos os atos que este prática.

Não havendo esses atributos, principalmente a ligação funcional entre o carteiro e o juiz, é praticamente impossível submeter aquele à disciplina judiciária, não se podendo assim considerá-lo um auxiliar do juízo.

Quando se atribui ao carteiro a relevante missão de proceder à ciłação de alguém, não deixa ele de ser um mero carteiro, não podendo ser equiparado, destarte, ao oficial de justiça.

3. Segundo a lei, pode ser citado através do correio o comerciante ou industrial. O conceito de comerciante não é próprio do Direito Processual Civil. O art. 222 é uma norma processual em branco, devendo ser preenchida por um conceito de Direito Comercial.

02. Egas Dirceu Moniz de Aragão, Comentários ao Código de Processo Civil, São Paulo Rio de Janeiro, Ed. Forense, 1974, vol. II, n. 240, págs. 205 e segs.

03. Waldemar Mariz de Oliveira Júnior, Curso de Direito Processual Civil, Teoria Geral do Processo de Conhecimento, São Paulo, Ed. Revista dos Tribunais, 1968, pág. 151.

04. Luiz Antonio de Andrade, Aspectos e Inovações do Código de Processo Civil, São PauloRio de Janeiro, Ed. Livraria Francisco Alves S/A., 1974, n. 100, pág. 90; José Carlos Barbosa Moreira, O novo Processo Civil Brasileiro, São Paulo - Rio de Janeiro, Ed. Forense, 1975, pág. 49. 
Será comerciante, para os fins do art. 222, todo aquele que for comerciante de conformidade com as leis que regulam a atividade comercial entre nós.

O prof. RUBENS REQUIÃO define comerciante como "aquele que faz da prática dos atos de comércio profissão habitual" (05). Enquadrado neste conceito encontra-se também o comerciante de fato, sem registro, que poderá ser igualmente citado pelo correio.

A citação postal pode abranger quer as sociedades comerciais, quer o comerciante individual que atua sob firma, seja a situação dos mesmos regular ou não do ponto de vista do registro.

Em decorrência disto, não se exige prova de registro na Junta Comercial para o deferimento do pedido de citação postal; basta a afirmação do autor e, havendo dúvidas, um mero cartão indicando a qualidade de comerciante será prova suficiente (06).

Evidentemente, em se sentindo prejudicado, ao citando cabe o ônus de provar que não é comerciante.

4. Outro aspecto que nos incumbe analisar é o referente aos limites existentes para a citação pelo correio. Pode o juiz de uma determinada comarca ordenar que se realize citação nos limites territoriais de outra?

Os arts. 200 e 201 do Código de Processo Civil traçam o âmbito territorial de atuação do juiz. Cada juiz pode mandar que se pratiquem atos dentro de sua comarca, não podendo daí extravassar. Apenas em uma única hipótese isto é possível, encontrando-se esta expressamente prevista no Código. Trata-se da citação feita por oficial de justiça de uma comarca em outra contígua à primeira e de fácil comunicação (art. 230).

Quanto à citação pelo correio poderia nascer uma dúvida decorrente da redação do art. 222, que alude a réu, comerciante ou industrial, domiciliado no Brasil. A interpretação literal deste artigo poderia levar a se entender que ele representa também uma exceção aos arts. 200 e 201 que delimitam a esfera de atuação do juiz à comarca a que se encontra ligado. Mas a interpretação literal é sempre perigosa e deve ceder ante à sistemática, que, no caso, nos conduz à exegese diversa.

06. Rubens Requião, Curso de Direito Comercial, São Paulo, Ed. Saraiva, 1971, n. 62, pág. 58 .

06. Neste sentido, decisão do II Tribunal de Alçada Civil do Estado de Sảo Paulo, 2.a Câmara, proferida no agravo de instrumento n. 23.832, rel. Barros Monteiro Filho, julgamento, por unanimidade, em 4 de dezembro de 1974. Tal decisão apoia-se no entendimento do prof. Egas Dirceu Moniz de Aragão (Comentários cit., págs. 206/207). 
Da análise do sistema vemos então, primeiramente, os arts. 200 e 201. Por outro lado, há toda uma preocupação do legislador com a disciplina das precatórias e das rogatórias, que são formas de comunicação com juízo de outra comarca. Facilita a lei sua transmissão (arts. 204 e 205), de forma a torná-las atuantes e não representarem um atravancamento à justiça.

Por outro lado, se formos à lei de alimentos (Lei n. ${ }^{\circ} 5.478$ de 25 de julho de 1968) constataremos que o legislador ao disciplinar aí a citação postal expressamente permitiu que ela fosse feita além das lindes da comarca (art. $5 .^{\circ}, \S 8^{\circ}$ ). Ora, se é necessário um preceito expresso autorizando a transposição do âmbito da comarca nas ações de alimentos é porque da disciplina geral da matéria não podemos chegar a esta mesma conclusão.

Assim, é esta a interpretação que vem prevalencendo desde há muito no campo trabalhista (07) onde da mesma forma não encontramos preceito expresso.

Em nosso entender somente poderá ser ordenada a citação pelo correio quando o réu for encontrável na comarca do juiz que a deferiu (08).

5. Nem toda demanda em que for réu comerciante ou industrial domiciliado no Brasil justifica a citação postal (09).

Primeiramente devemos afastar todas as ações desligadas, de forma direta ou indireta, da atividade comercial do indivíduo. Não pode ser feita por esta forma a citação em uma ação de desquite contra determinada pessoa cuja profissão é comerciante.

Autorizada está a citação postal unicamente nas demandas relativas à atividade comercial, ainda que este relacionamento seja apenas indireto. Assim uma ação decorrente da prática de um ato comercial abre ensejo a citação postal, não há dúvida alguma; mas também uma demanda, ligada de forma indireta a esta atividade, permite a realização da citação pelo correio. É o que se dá, v.g., com uma ação de reparação de danos causados por veículo de uma empresa. Nesta hipótese, apesar da ação não decorrer especifica-

07 Amauri Mascaro do Nascimento, Elementos de Direito Processual do Trabalho, São Paulo, Ed. LTr., 1973, pág. 149; Eduardo Gabriel Saad, Consolidação das Leis do Trabalho Comentada, São Paulo, Ed. LTr., 6.a ed., 1974, pág. 301.

08. Diversamente: Arruda Alvim, mesa de debates do V Curso de Especialização em Direito Processual Civil, promovido pelo Setor de Especialização da Pontifícia Universidade Católica de São Paulo e coordenado pelo referido professor, sessão de 11 de outubro de 1975.

09. Sem razão, José Frederico Marques, Manual de Direito Processual Civil, São Paulo, Ed. Saraiva, 1974, 1.a ed., n. 285, pág. 33. 
mente da prática de um ato comercial, ela tem como réu um comerciante ou industrial enquanto tal.

6. Quanto ao modo de sua realização temos que observar o que se segue: dispõe a lei que ela deve ser requerida, no que acrescenta o prof. BARBOSA MORE:RA, com muita propriedade, que deve ser deferida e não apenas requerida (10), uma vez que o juiz, caso não se configurem os pressupostos de sua admisibilidade, poderá indeferí-la, mandando que seja realizada através do oficial de justiça.

A citação postal está dentro do poder dispositivo do autor que poderá preferíla ou não. O momento normal para se requerer a citação postal é o da petição inicial (art. 282, VII), mas nada impede que a opção por esta modalidade seja feita em momento posterior.

Requerida e deferida, os atos seguintes ficam a cargo do escrivão ou do chefe da secretaria que, de conformidade com o art. 223 do Código de Processo Civil, "porá a cópia da petição inicial, despachada pelo juiz, dentro de sobrescrito com timbre impresso do juízo ou tribunal, bem como do cartório, indicando expressamente que visa a intimar o destinatário".

A carta, devidamente registrada e com aviso de recepção (A. R.), deverá ser entregue ao destinatário, como se lê no art. $223, \S 3 .^{\circ}$. Este termo empregado pelo legislador traz a lume a dificuldade maior de toda a problemática da citação postal.

Se nós examinarmos os diversos artigos do Código onde temos disciplinada a citação, veremos que o legislador empregou sempre ou a paalvra réu, como, por exemplo, nos arts. 226, 227, 229, 231 e outros, ou o termo citando, conforme os arts. 228, 230 e outros. Quando da regulamentação da citação postal trouxe à cena um novo termo: destinatário

Ciłando e réu não deixam a menor sombra de dúvida quanto ao caráter pessoal da citação. Já destinatário, ainda mais tendo-se em vista que a citação postal destina-se a organizações, nos causa alguma perplexidade, consistente em se identificar exatamente quem - seja, isto é, será válida a citação pelo correio se a carta, ao invés de ser entregue ao representante legal da empresa ou ao próprio comerciante ou industrial em nome individual, o for a qualquer pessoa ligada ao estabelecimento (porteiro, secretária, recepção, protocolo)?

10. José Carlos Barbosa Moreira, op. cit., pág. 49. 
A resposta que se nos impõe a esta questão é negativa.

Primeiramente, a citação é o ato mais importantes do processo, representando, consoante a lição de ARRUDA ALVIM, um direito impostergável do réu resultante de toda a evolução histórica por que passou a humanidade (11). Este ato deve ser revestido da maior segurança possível, dando-se-lhe todo um aparato capaz de the assegurar sua dignidade.

Por outro lado, quando o Código regula a citação, dispõe no art. 215 que ela deve ser feita pessoalmente ao réu, ao seu representante legal ou a procurador autorizado.

Admite, no entanto, que ela seja feita a outrem diante de situações excepcionais que os parágrafos do artigo referido minuciosamente contemplam. Por um outro aspecto, quando a lei derrogou essas regras, fê-lo de forma taxativa, como se pode ver no art. 38 que regula a citação dos opostos, mandando que seja feita na pessoa do advogado destes.

Da análise desses textos do Código decorre a pessoalidade do ato citatório. Requer-se, como um dos princípios fundamentais do processo, que a citação seja feita na pessoa do próprio réu ou, em se tratando de pessoa jurídica, na figura de seu representante legal. Ora, não será o simples emprego pelo legislador de uma palavra sinônima que irá derrogar a regra da individualidade da citação.

Se formos, finalmente, examinar as consequências da revelia no sistema de 1973, veremos que elas são exageradamente drásticas, o que é incompatível com a simplicidade da citação pelo correio em situação que não a da entrega da carta pessoalmente ao citando.

Tendo em vista essas premissas, entendemos que a carta registrada deve ser entregue ao representante legal da empresa ou do próprio réu comerciante ou industrial, ou a quem tem poderes especiais para recebê-la, não sendo válida se feita de outra forma, isto é, se entregue no protocolo, ao porteiro, à recepcionista etc. (12).

Evidentemente a partir desta idéia, esvazia-se muito o sentido da citação por carta, pois não será fácil ao carteiro ter acesso ao di-

11. Arruda Alvim, Código de Processo Civil Comentado, São Paulo, Ed. Revista dos Tribunais, 1975, I vol., pág. 57.

12. I Tribunal de Alçada Civil do Estado de São Paulo, 4.a Câmara, Agravo de Instru mento n. 309.818, Comarca de Taquaritinga, rel. Bandeira de Mello, v.u., 12 de março de 1975 . 
retor ou ao gerente de uma grande empresa, para colher deste a assinatura no aviso de recepção. Esta modalidade citatória, na realidade, vai servir unicamente contra o pequeno comerciante ou industrial que é facilmente encontrado atrás de seu balcão, mas para o grande industrial, não! Este nunca vai ser atingido.

A dificuldade de realização da citação postal está em que o carteiro não tem os poderes que tem o oficial de justiça para adentrar em um recinto; ainda, e por outro lado, quando o representante ou o réu se recusar a assinar o aviso de recepção, cumpre ao carteiro devolver a carta, pois, diferentemente do oficial de justiça, não pode certificar com fé pública que o citando recusou-se a recebê-la (13).

7. Não encontrando o representante legal da pessoa jurídica ou o comerciante individual, resta ao carteiro unicamente devolver a correspondência, pois não tem poderes para proceder de forma diversa, nem condições de ir procurar o citando, fora do local indicado. Destarte, ou o carteiro encontra o réu no endereço para o qual foi enviada a carta, ou simplesmente a devolve.

O procedimento deve ser o mesmo quando o réu recusa-se a assinar o aviso de recepção, uma vez que, conforme já afirmamos anteriormente, não tem fé pública eventual declaração do carteiro neste sentido (14).

Diante da devolução da carta, deve o juiz determinar, mesmo de ofício, que se procede à citação por mandado, que é a forma comum de citação.

8. No momento da realização da citação, operam-se efeitos de natureza processual e material. Entre os primeiros temos a prevenção, a litispendência e a litigiosidade da coisa, sendo que, entre os materiais, encontramos a constituição do devedor em mora e a interrupção da prescrição, ressalvando-se, quanto ao último, que a sua ocorrência será no momento da citação somente se esta não se der no prazo de dez dias ou no de noventa dias, concedidos pelo juiz, a contar da data do despacho da petição inicial. Caso a citação se dê neste lapso de tempo, a interrupção da prescrição será tida como operada contemporaneamente ao despacho inicial e não à citação (art. 219).

Quando a citação realizar-se por via postal, a ocorrência desses efeitos dar-se-á igualmente no momento da citação (com a mesma ressalva quanto à interrupção da prescrição), o que, no entanto,

13. Contrariamente, José Frederico Marques, op. cit., n. 285, pág. 333.

14. José Carlos Barbosa Moreira, op. cit. pág. 49. 
somente poderá ser constatado quando da devolução do aviso de recepção devidamente assinado, oportunidade em que se constatará o dia de sua realização.

Referentemente ao prazo para resposta, sua fluência será a partir da juntada aos autos do A.R. assinado pelo réu ou pelo representante legal da empresa (art. 241, V).

9. O Código de Processo Civil tem sido objeto de críticas por não ter um livro de disposições gerais que seriam aplicáveis a todos os processos por ele disciplinados. Mas grande parte da matéria regulada do Livro I (Processo de Conhecimento), pela sua própria natureza, tem a força de servir de regra geral.

Ao lado deste aspecto, encontramos no Livro II, que trata do Processo de Execução, um preceito mandando aplicar subsidiariamente as regras do processo de conhecimento ao de execução (art. 598).

A questão que se coloca diante desses postulados é a de saber se seria possível realizar-se citação pelo correio em processo de execução, quando o devedor fosse comerciante ou industrial.

A resposta afirmativa poderia ser tirada do art. 598 por nós referido e do caráter de normas gerais que possuem diversos dos institutos disciplinados no Livro atinente ao processo de conhecimento, como o é a citação. Entretanto, a especificidade do processo de execução não abre oportunidade para a realização da citação postal. Ainda, toda aplicação subsidiária supõe compatibilidade entre os preceitos, o que não se dá no caso em tela.

Primeiramente devemos atentar para a própria regulamentação minuciosa do art. 625 que prevê sempre a citação pelo oficial de justiça. Por outro lado, a citação na execução deve ser complementada no prazo de vinte e quatro horas com a penhora dos bens do devedor, caso este não proceda ao pagamento do quantum devido, o que seria irrealizável diante da citação postal, haja vista a demora inevitável na devolução do A.R. Finalmente, atribui a lei poder ao oficial de justiça de arrestar bens do devedor caso os encontre e não consiga realizar a citação (art. 653), o que também não poderia ser feito pelo agente do correio.

Assim, a citação pelo correio não pode ser realizada no processo de execução porque sua disciplina é inadaptável às regras deste processo. 